\title{
MANAJEMEN STRATEGI PERUSAHAAN
}

Makalah ini disusun guna memenuhi tugas mata kuliah

"PENGANTAR MANAJEMEN"

Dosen Pembimbing :

Dra. Hj. Nuraeni Gani.M.M

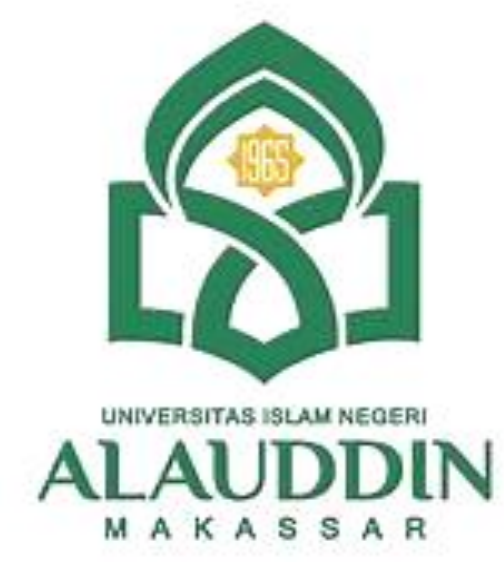

DISUSUN OLEH :

NURUL UYUN

90500121016

PRODI PERBANKAN SYARIAH

FAKULTAS EKONOMI DAN BISNIS ISLAM

UNIVERSITAS ISLAM NEGERI MAKASSAR

2021 M / 1443 


\section{KATA PENGANTAR}

\section{KATA PENGANTAR}

Alhamdulillah, segala puja dan puji syukur kehadirat Allah swt. Yang telah memberikan kami kesehatan serta kesempatan sehingga kami bisa mengerjakan serta menyelesaikan makalah ini.

Shalawat serta salam semoga selalu terlimpah kepada Rasulullah Muhammad saw. yang telah menyampaikan risalah wahyu sebagai petunjuk untuk meraih kebahagiaan di dunia dan akhirat kelak.

Selanjutnya, terima kasih kami ucapkan kepada Ibu Dra. Hj. Nuraeni Gani.M.M selaku dosen pembimbing mata kuliah “PENGANTAR MANAJEMEN " ini, atas bimbingannya. Alhamdulillah kami dapat menyelesaikan makalah ini meskipun masih banyak terdapat kekurangan di dalamnya. Karena itu, kritik dan saran sangat kami harapkan dalam upaya penyempurnaan makalah ini. Akhirnya, semoga makalah ini dapat memberi manfaat kepada kita semua. Amin.

Samata Gowa, 04 Desember 2021

Nurul Uyun 


\section{DAFTAR ISI}

HALAMAN SAMPUL ....................................................... Error! Bookmark not defined.

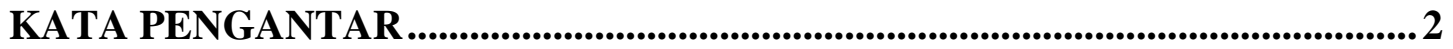

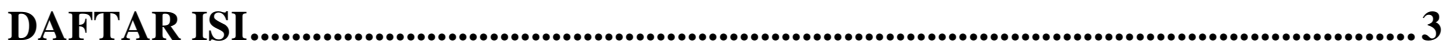

BAB I_ PENDAHULUAN

a. Latar Belakang ……………………………………………………….... 4

b. Rumusan Masalah ...................................................................................... 4

c. Tujuan dan manfaat penulisan ....................................................................... 4

\section{BAB II_PEMBAHASAN}

a. Definisi Perilaku Individu Dalam Organisasi................................................... 5

b. Faktor individu dan implementasi rencana organisasi .................................... 5

c. Memahami faktor individu dalam organisasi .................................................. 6

d. Perilaku dan kepribadian individu ................................................................ 7

e. Perilaku Individu Lainnya Yang Memengaruhi Organisasi .............................. 8

f. Perilaku Individu Dan Sikap Dalam Berorganisasi ......................................... 8

g. Perilaku Individu Dan Persepsi Dalam Berorganisasi ..................................... 9

h. Mengelola individu dalam organisasi.......................................................... 9

\section{BAB III PENUTUP}

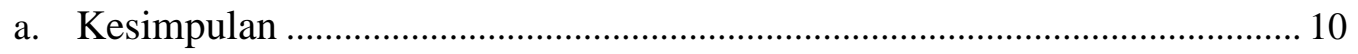

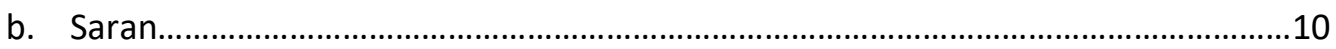

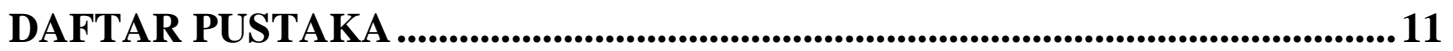




\section{BAB I}

\section{PENDAHULUAN}

\section{A. Latar Belakang}

Faktor individu sangat berpengaruh dalam organisasi. Kunci utama dalam fungsi pengarahan dan implementasi adalah pemahaman atas karakteristik dan peran individu dalam organisasi. Keragaman karakteristik individu perlu dipahami manajer sebelum implementasi dan fungsi pengarahan dilakukan.hal tersebut disebabkan karena keragaman individu dapat memberikan dampak berlawanan satu sama lain. Dampak positif ketika keragaman tersebut menjadi potensi untuk saling melengkapi, atau sebaliknya, dampak negative sebagai sumber konflik bagi organisasi. Perilaku merupakan hal menarik untuk dipelajari baik perilaku individu maupun perilaku kelompok, hal ini sangat penting karena dengan mengetahui arti dari perilaku kita dapat mengetahui apa yang diinginkan oleh individu tersebut. Hal ini bertujuan agar apa yang kita harapkan dapat tercapai dengan kerjasama setiap individu dengan keanekaragaman perilakunya. Selain itu perilaku dalam sebuah organisasi sangat mempengaruhi jalannya suatu organisasi tersebut.

\section{B. Rumusan Masalah}

1. Pengertian perilaku individu dalam organisasi?

2. Apa saja faktor individu dan implementasi rencana organisasi?

3. Bagaimana memahami faktor individu dalam organisasi?

4. Mengetahui perilaku dan kepribadian individu?

5. Apa perilaku individu lainnya yang mempengaruhi organisasi?

6. Apa perilaku individu dan sikap dalam organisasi?

7. Apa saja perilaku individu dan perpepsi dalam organisasi

8. Bagaimana mengelolah individu dalam organisasi?

\section{Tujuan dan manfaat penulisan}

1. Untuk memenuhi tugas mata kuliah pengantar Manajemen 
2. Untuk menambah wawasan dan pengetahuan tentang perilaku dan faktor dalam organisasi

\section{BAB II}

\section{PEMBAHASAN}

\section{A. Definisi Perilaku Individu Dalam Organisasi}

Perilaku keorganisasian merupakan bidang studi yang mempelajari tentang interaksi manusia dalam organisasi, meliputi studi secara sistematis tentang perilaku, struktur dan proses dalam organisasi. Sedangkan perilaku individu adalah sebagai suatu fungsi dari interaksi anatara individu dengan lingkungannya. Individu membawa tatanan dalam organisasi berupa kemampuan, kepercayaan pribadi, penghargaan, kebutuhan, dan pengalaman masa lainnya. Perilaku individu juga dapat disebut sebagai perilaku atau interaksi yang dilakukan sangatlah berbeda dan hal ini dipengaruhi oleh lingkungan dimana individu tersebut tinggal, untuk itu perlunya suatu organasasi agar kebutuhan yang berbeda tersebut dapat dipenuhi denagn bekerja sama anatara individu. Perilaku individu akan membentuk pada perilkau organisasi.

\section{B. Faktor individu dan implementasi rencana organisasi}

Dalam fungsi pengeroganisasian dimulai desain organisasi hingga penempatan SDM untuk menjalankan rencana organisasi, angka berikutya tentu, adalah keseluruhan rencana yang telah diatur menurut struktur organisasi dapat diimplementasikan. Apabila dalam manajemen SDM perusahaan berusaha mendapatakan tenaga kerja yang terbaik untuk dapat bekerja sesuai dengan jabatan-jabatan yang ada dalam organisasi, maka dengan demikian langkah implementasi sangat ditentukan oleh sampai sejauh mana SDM perusahaan yang 
telah dipilih dan ditempatkan tersebut menunjukkan kinerja terbaik. Dengan demikian, maka faktor SDM kembali menjadi kunci penting dalam implementasi. Implementasi dari rencana organsasi sangat bergantung kepada karakteristik individu yang terdapat dalam organisasi. Oleh karena itu perusahaan perlu memahami lebih jauh mengenai karakteristik individu tersebut, termasuk sifat dan perilaku setiap individu diperusahaan.

\section{Memahami faktor individu dalam organisasi}

Terdapat tiga faktor lain, ketiga faktor itu adalah yang terkit dengan kontrak psikologi, kesesuaian tenaga yang dibutuhkan perusahaan dan keragaman individu setiap organisasi.

1. Kontrak psikologis

Kontrak psikologis adalah suatu kesepakatan yang tertulis yang muncul ketika seorang bergabung dengan sebuah organisasi atau ketika tenaga kerja bergabung dengan perusahaan.

2. Kesesuain tenaga kerja yang dibutuhkan perusahaan

Kesesuain tenaga kerja yang dibutuhkan perusahaan terkait dengan individu dari tenaga kerja. Dalam kenyataaan perusahaan tidak pernah mendapatkan tenaga kerja yang benar-benar sesuai dengan kriterianya.

3. Keragaman individu dalam organisasi

Keragaman individu dalam organisasi adalah manusia yang ditakdirkn tidak sama, baik dari sisi latar belakang biologisnya, latar belakang pendidikan, hingga berbagai faktor yang mempengaruhi karakteristik setiap individu tenaga kerja. Oleh karena itu, perusahaan perlu memahami keragaman secara lebih terbuka dan menerimanya sebagai dinamika yang terdapat dalam organisasi manapun. 


\section{Perilaku dan kepribadian individu}

Kepribadian pada dasarnya merupakan karakteristik psikologi dan perilaku dari individu yang sifatnya relative permanen yang membedakan satu individu dengan individu lainnya. Manager dituntut untuk memahami kepribadian setiap individu agar manager bisa mengetahui bagaimana cara terbaik untuk menghadapi mereka. Pemahaman yang harus diketahui manager adalah apa yang dinamakan sebagai "model lima dimensi mengenai kepribadian" sebagaimana yang dikemukakan oleh GRIFFIN (2000). Model ini menjelaskan bahwa pada dasarnya kepribadian dapat didefinisikan dari lima djenis perilaku yang terdapat pada setiap individu.

1. Agreeableness (tingkat persetujuan)

Tingkat persetujuan menunjukkan tingkat kemapuan individu dalam berinteraksi dan bekerja sama dengan orang lain.

2. Conscienctiousness (keseriusan dan kesadaran)

Tingkat keseriusan dan kesadaran menunjukkan tingkat keseriusan individu terhadap rencana pencapaian tujuan dari organisasi.

3. Negative Emotionally (Tingkat emosi yang negative)

Tingkat yang negative menunjukkan ketidak stabilan emosi yang dimiliki oleh individu.

4. Extraversion (Tingkat keleluasaan dan kenyamanan)

Tingkat keleluasaan dan kenyamanan menunjukkan kepada kemampuan individu untuk merasa nyaman dan leluasa bagi orang lain untuk berinteraksi dengannya.

5. Openness (tingkat keterbukaan)

Tingkat keterbukaan menunjukkan kepada perilaku individu untuk bersikap terbuka terhadap orang lain. 


\section{E. Perilaku Individu Lainnya Yang Memengaruhi Organisasi}

1. Locus of control

Locus of control menunjukkan kepada sebuah keyakinan yang dimiliki individu mengenai hasil yang mereka peroleh merupakan akibat dari apa yang mereka lakukan.

2. Self efficacy

Self efficacy menunjukkan kepada kepercayaan diri dari individu untuk dapat melakukan sesuatu.

3. Authoritarianism

Authoritarianism menunjukkan kepada keyakinan individu akan peran tingkatan hierarki dalam sebuah organisasi dan kaitannya dengan kekuasaan dalam organisasi.

4. Machiavellism

Menunjukkan kepada perilaku kepada perilaku untuk merekayasa perilaku orang lain selama rekayasa perilaku tersebut akan membantu kita dalam mencapai tujuan.

5. Self esteem

Menunjukkan kepada sebuah keyakinan dari seseorang atau individu bahwa dirinya layak untuk mendapatkan penghargaan.

6. Risk propensity

Menunjukkan kepada kecenderungan individu dalam hal resiko dan menjawab tantangan.

\section{F. Perilaku Individu Dan Sikap Dalam Berorganisasi}

Sikap atau attitude pada dasarnya merupakan prinsip yang diambil oleh individu berdasarkan kepribadian, keyakinan, dan perasaan yang menyangkut suatu gagasan, situasi, atau lingkungan yang dihadapinya. GRIFFIN menjelaskan bahwa sikap memiliki tiga komponen utama, yaitu komponen efektif, kognitif, 
dan intense. Komponen efektif menyangkut perasaan yang dirasakan seorang mengenai gagasan, situasi atau lingkungan yang dihadapinya. Komponen kognitif menyangkut pengetahuan seseorang mengenai sesuatu yang terkait dengan gagasan, situasi maupun lingkungan yang dihadapinya. Komponen intense yaitu menyangkut harapan dari seseorang sebagai akibat dari gagasan, situasi maupun lingkungan yang dihadapinya.

\section{G. Perilaku Individu Dan Persepsi Dalam Berorganisasi}

1. Persepsi selektif yaitu proses penyelesaian informasi mengenai sesuatu dimana sesuatu tersebut mengalami berbagai kontradiksi dan ketidaksesuaian dari persepsi awal yang kita yakini.

2. Streotip yaitu pelabelan terhadap seseorang berdasrkan suatu kejadian tertentu yang dialami atau dilakukan oleh seseorang tersebut.

\section{H. Mengelola individu dalam organisasi}

Kinerja merupakan penampilan hasil kerja pegawai baik secara kuantitas maupun kualitas. Kinerja dapat berupa penampilan kerja peronrangan maupun kelompok kinerja organisasi merupakan hasil interaksi yang kompleks dan agregasi kinerja sejumlah individu dalam organsasi.

Untuk mengetahui faktor yang mempengaruhi (determinan) kinerja individu, perlu dilakukan pengkajian terhadap teori kinerja. Secara umum faktor fisik dan non fisik sangat mempengaruhi. Berbagai kondisi lingkungan fisik kondisi sangat mempengaruhi kondisi lingkungan fisik juga akan mempengaruhi berfungsinya faktor lingkungan non fisik. Pada kesempatan ini pembahasan kita fokuskan pada lingkungan non fisik, yaitu kondisi-kondisi yang sebenarnya sangat melekat dengan sistem manajerial perusahaan. 


\section{BAB III}

\section{PENUTUP}

\section{A. Kesimpulan}

Dari pembahasn diatas dapat disimpulkan bahwa keberhasilan perusahaan dalam mengimplementasikan rencana perusahaan yang telah direncanakan ditentukan oleh SDM yang dimiliki oleh perusahaan itu, dan dalam membentuk SDM yang baik perusahaan ini harus memerhatikan betul tentang kesejahteraan SDM tersebut.

Perilaku individu dalam organisasi adalah bentuk interaksi antara karakteristik individu dengan karakteristik organisasi. Setiap individu dalam organisasi, semuanya akan berperilaku berbeda satu sama lain, dan perilakunya adalah ditentukan oleh masing-masing lingkungannya yang memang berbeda. Individu membawa ke dalam tatanan organisasi kemampuan., kepercayaan pribadi, pengharapan kebutuhan dan pengalaman masa lalunya. Organisasi merpakan suatu lingkungan yang mempunyai karakteristik seperti keteraturan yang diwujudkan dalam susunan hirarki, pekerjaan, tugas, wewenang, tanggung jawab, sistem pengajian, dan sistem pengendalian.

\section{B. Saran}

Saya berharap makalah ini dapat membantu bagi seluruh Mahasiswa khususnya para pembaca agar dapat meningkatkan pengetahuan tentang faktor individu dalam organisasi dan dapat menambah pengetahuan bagi rekan-rekan mahasiswa. Demi penyempurnaan makalah ini, kami mengarapkan kritik dan saran yang konstruktif. 
DAFTAR PUSTAKA

https://www.academi,edu/22208951/MAKALAH-perilaku-individu-dalam-organisasi https://tuxdoc.com/download/makalah-faktor-individu-dalam-organisasi-pdf 
